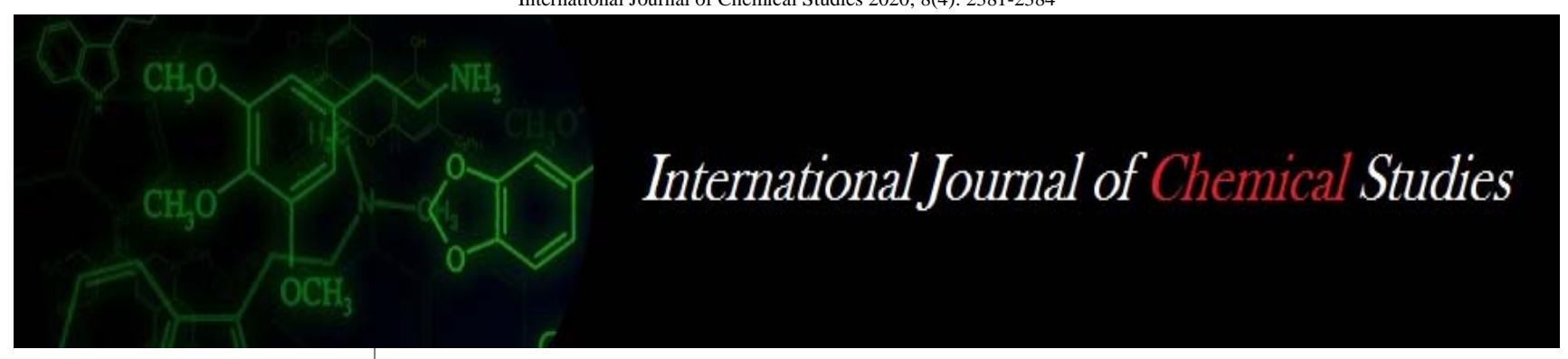

P-ISSN: 2349-8528 E-ISSN: 2321-4902 www.chemijournal.com IJCS 2020; 8(4): 2381-2384 (C) 2020 IJCS

Received: 13-05-2020 Accepted: 16-06-2020

Shish Ram Dhikwal Department of Agronomy, Collage of Agriculture Bikaner, Swami Keshwanand Rajasthan Agriculture University Bikaner Rajasthan, India

SM Kumawat Department of Agronomy, Collage of Agriculture Bikaner, Swami Keshwanand Rajasthan Agriculture University Bikaner Rajasthan, India

Corresponding Author: SM Kumawat Department of Agronomy, Collage of Agriculture Bikaner, Swami Keshwanand Rajasthan Agriculture University Bikaner Rajasthan, India

\section{Wheat productivity influenced by time of sowing, cultivars and bio regulators}

\author{
Shish Ram Dhikwal and SM Kumawat
}

DOI: https://doi.org/10.22271/chemi.2020.v8.i4aa.9990

\section{Abstract}

A field experiment was conducted on sandy loam soil of the Instructional Farm, College of Agriculture, Swami Keshwanand Rajasthan Agricultural University, Bikaner during consecutive two rabi seasons of 2012-13 and 2014-15. The experiment consisted two sowing dates i.e., $20^{\text {th }}$ November (timely) and $15^{\text {th }}$ December (late) and four wheat cultivars viz., Raj 4083, Raj 3765, Raj 4120 and Raj 1482 in main plots and in sub plots two foliar sprays (at 45 and 75 DAS) of bioregulators namely $\mathrm{N}$ - acetyl- L- cysteine (20 $\mathrm{ppm})$, salicylic acid (200ppm) and water spray control (WSC). The results reveal that sowing the wheat cultivars on $20^{\text {th }}$ November (timely) significantly increased yield attributes namely number of effective tillers $\mathrm{m}^{-1}$ row length, number of grains per spike, spike length and test weight also recorded significantly higher in timely sown wheat cultivars compared to late sown crop. Further results indicated that grain, straw and biological yields improved significantly in timely sown wheat. The increases was to the tune of $14.53,8.80$ and 11.20 per cent, respectively compared to late sowing condition. The spike $\mathrm{m}^{-1}$ row length, test weight, seed, straw and biological yields were significantly higher in wheat cultivar Raj 4120 compared to Raj 4083, Raj 3765 and Raj 1482. Foliar spray of bioregulators viz., N-acetyl-L-cysteine (20 ppm) and Salicylic acid (200 ppm) significantly increased above mentioned parameters.

Keywords: wheat, yield attributes, yield, salicylic acid, n-acetyl-l-cystein

\section{Introduction}

Wheat (Triticum aestivum L.) is one of the most important staple food crops of the world as well as India. It is cultivated under diverse growing conditions of soil and climate. In India, it is the second most important food crop after rice. It is an excellent health-building food containing approximately $78 \%$ carbohydrates, $12 \%$ protein, $2 \%$ fat and minerals each and considerable amount of vitamins (Kumar et al., 2011) ${ }^{[13]}$. It is cultivated mainly in the states of Uttar Pradesh, Madhya Pradesh, Punjab, Rajasthan, Haryana, Bihar, Gujarat and Maharashtra. Among the different states of India, Uttar Pradesh ranks first in area and total production, while Punjab ranks first in productivity. An optimistic feature of wheat research will have to come from increased productivity of available wheat varieties, have yielding ability as much as 60-65q ha-1. At present, on an average, we are harvesting only about half of the potential yield of the wheat varieties in the country. Genetic potential and heat stress escaping quality of a genotype may overcome the heat stress problem in North Western part of Rajasthan. Therefore the varieties which have such type of potential may be tested and need attention. The application of bioregulators is known to play an important role in plant response to stresses (Chakrabarti and Mukherjee, 2003) ${ }^{[6]}$. Salicylic acid has recently been recognized as growth regulator (Hayat et al., 2007) ${ }^{[9]}$, which plays diverse physiological roles in plants including thermogenesis, flower induction, nutrient uptake, ethylene biosynthesis, stomata movement, photosynthesis and enzyme activities. Application of salicylic acid induces the chalcone synthase and phenylalanine amylase activity that cumulatively confer resistance during stress (Campos et al., 2003) ${ }^{[5]}$. Earlier reports indicated that salicylic acid (SA), also affects the expression of genes for glutathione-s-transfer, which are involved in protection against oxidative stress (Chen et al., 1996 and Sharma et al., 1996) ${ }^{\text {[7, 9] }}$, and it enhanced the activity of the alternative pathway of respiration, which may prevent harmful production of free radicals in mitochondria (Wagner, 1995) ${ }^{[24]}$. N-acetyl-L-cysteine a sulphydryl compound has bioregulatory effects in several ways which together result in improving plant performance $\mathrm{W}$ and yielding ability. The sulphydryl compounds seem to have decisive role in improving 
phloem loading of sucrose and dry matter partitioning (Sahu et al., 1991, Sahu and Singh 1995) ${ }^{[17,[16]}$ and also have potential in improving desiccation tolerance, primarily caused by deficiency of water.

\section{Materials and methods}

The experiment was conducted at Instructional Farm, College of Agriculture, Swami Keshwanand Rajasthan Agricultural University, Bikaner. Geographically, Bikaner is situated at $28.01^{\circ} \mathrm{N}$ latitude and $73.22^{\circ} \mathrm{E}$ longitude and at an altitude of 234.70 meters above mean sea level. The location falls under agro climatic zone- 1c (Hyper arid partially irrigated north western plain) of Rajasthan. Bikaner receives average annual rainfall of about $250 \mathrm{~mm}$, out of which 80 per cent is received in kharif season (July to September) by the southwest monsoon. During summer, the maximum temperature may go as high as $48{ }^{\circ} \mathrm{C}$ while in the winter it may fall as low as $0{ }^{\circ} \mathrm{C}$. This region is prone to high wind velocity and soil erosion due to dust storms in summer. The maximum temperature ranged between 17.5 to $36.2{ }^{\circ} \mathrm{C}$ and $19.2{ }^{\circ} \mathrm{C}$ to $35.6{ }^{\circ} \mathrm{C}$ during 2012-13 and 2014-15, respectively. Likewise, the minimum temperature ranged between $0.6{ }^{\circ} \mathrm{C}$ to $17.3{ }^{\circ} \mathrm{C}$ and $4.6{ }^{\circ} \mathrm{C}$ to $19.2{ }^{\circ} \mathrm{C}$ during 2012-13 and 2014-15. During crop season of 2012-13, a total of $32.90 \mathrm{~mm}$ rainfall was received in 5 rainy days, whereas during 2014-15, $90.2 \mathrm{~mm}$ rainfall was received but more than $50 \%$ of it was received in 2 rainy days only. The maximum and minimum relative humidity was ranging between $45.0,88.6 \%$ and $10.9,37.7 \%$ during 2012-13 and 52.0, 86.7\% and 12.4, 49.9\% during 2014-15, respectively. The soil of the experimental field was sandy loam in texture, poor in organic carbon, low in available nitrogen, medium in available phosphorous but high in available potassium and slightly alkaline in reaction. The experiment was laid out in split plot design with three replications. Each plot consisted gross dimension of $4.5 \mathrm{~m} \times 3.0 \mathrm{~m}$ and net area $3.5 \mathrm{~m} \times 1.80$ $\mathrm{m}$. Sowing was done at row to row spacing of $20 \mathrm{~cm}$ apart towards width dimension of $3.0 \mathrm{~m}$, thus 15 rows in each plots. After pre- sowing irrigation (palewa), the experimental field was prepared with tractor by cross harrowing followed by planking to bring the field in to good tilth for batter germination and establishment of crop. Each treatment plot was demarcated as per plan of layout. At the time of final field preparation, basal dose of $60 \mathrm{Kg} \mathrm{N}, 40 \mathrm{Kg} \mathrm{P}_{2} \mathrm{O}_{5}$ and 20 $\mathrm{kg} \mathrm{K}_{2} \mathrm{O}$ ha $^{-1}$ through Urea, DAP and MOP was drilled below the seed zone. Zinc sulphate (33\%) @ $25 \mathrm{~kg} \mathrm{ha}^{-1}$ was also drilled along with basal application of major nutrients. The remaining $1 / 2$ dose of nitrogen i.e., $60 \mathrm{~kg} \mathrm{~N}^{\mathrm{N}} \mathrm{ha}^{-1}$ was top dressed in two equal splits with the first and third irrigation. Foliar spray of bioregulators viz., salicylic acid (200 ppm) and $\mathrm{N}$-acetyl-L-Cysteine (20 ppm) and (control) water spray were applied twice first at tillering (45 DAS) and second at heading /flowering (75 DAS) stages. Net plot area was harvested separately from each gross plot. The harvested material from each net plot was tied up in bundles, tagged properly and kept on threshing floor for sun drying. After complete sun drying, these bundles (of individual plot) were weighed to record biological yield. Threshing was done with power operated plot thresher followed by winnowing and cleaning manually and there grain yield per plot was recorded. The straw yield per plot was computed by subtracting grain yield from the biological yield of individual plot. The statistical analysis of the data on growth characters, yield attributes, yield and quality parameters were done by using the analysis of variance technique. Significance of the differences between treatment effects was tested by 'F' test. The critical difference at $5 \%$ level of probability was calculated wherever the differences were found significant. To elucidate the nature and magnitude of treatment effects, summary tables along with S.Em +and CD at 5\% were prepared.

\section{Results and discussion \\ Sowing dates}

The yield components namely 50\% spike emergence, grain development rate, effective tiller $\mathrm{m}^{-1}$ row length, spike length, number of grain per spike and test weight were found significantly higher under timely sowing compared to late sowing of wheat. Timely sowing $\left(20^{\text {th }}\right.$ November) proved most optimum for realization of higher productivity in terms of grain, straw and biological yields (Table1). The significant improvement in yield components under timely sowing of wheat crop seems to be on account of increased capacity of the crop to exploit available resources better and thereby production of more photosynthesis under congenial environment conditions. Whereas, late sowing of wheat results in reduced grain, straw and biological yield by 3.58 , 2.97 and $6.5 \mathrm{q} \mathrm{ha}^{-1}$, respectively over timely sowing (Table 2). Further, the harvest index of wheat also noted significantly higher in timely sowing compared to late sowing crop which indicated that the timely sowing contributed more metabolites/ assimilates towards the sink (grain) as compared to late sowing. The significant increase in straw yield under timely sowing seems to be on account improvement in overall growth of the crop in terms of plant height, tillers $\mathrm{m}^{-1}$ row length, LAI and dry matter accumulation along with the various morphological structures. Further, increased grain and straw yield under timely sown wheat cultivars resulted to higher findings of mutilocations trials conducted in north western plain zone by several researches Anonymous, 1994a and 1995b who reported more number of spikes, number of grains per spike and test weight under timely sowing. Also, these results are in cognizance with the findings of other researchers namely Khokhar et al., $2010^{[10]}$ in Pakistan, Lake et al., $2013^{[14]}$ in Iran and Suleiman et al., $2014^{[23]}$ in Sudan.

\section{Wheat cultivars}

It was evident that yield components i.e., spike $\mathrm{m}^{-1}$ row length and test weight were significantly higher in wheat cultivar Raj 4120 compared to Raj 4083, Raj 3765 and Raj 1482 (Table1). Wheat cultivar Raj 4120 also produced significantly higher grain, straw and biological yield compared to Raj 4083, Raj 3765 and Raj 1482 (Table2). The marked increase in number of spikes $\mathrm{m}^{-1}$ row length and test weight by cultivar Raj 4120 might be due to its genetic potential and improved growth parameters at successive stages as reflected by higher number of total tillers and effective tillers per metre row length and as well production of biomass $\mathrm{m}^{-1}$ row length. Besides environmental factors, growth and development of wheat depends upon supply of growth inputs (both metabolites and nutrients). The inadequate supply of these growth inputs, resulted poor initiation of tillers (due to depressed growth of lateral buds at early stage) and later on increased competition between vegetative and reproductive parts, restrict development of individual tiller and its transformation to spike bearing shoots (effective tiller). In wheat, the potentials of various yield components are decided during vegetative phase (after double ridge formation), while reproductive phase affects their realisable number. Thus, least competition between reproductive and vegetative growth structures for metabolites due to higher production of dry matter in wheat cultivar Raj 4120 led to higher effective tillers $\mathrm{m}^{-1}$ row length 
and further grain, straw and biological yield as compared to rest cultivars Raj 4083, Raj 3765 and Raj 1482. The results of present investigation on wheat are in conformity with those of Sandhu et al. (1999) ${ }^{[18]}$ in wheat, Kulhari (2000) ${ }^{[11]}$ in wheat and Lak et al. (2013) ${ }^{[14]}$ in wheat.

Since yield formation is a complex process and governed by interaction between source (photosynthesis and availability of assimilates) and sink component (store organs). Thus, as a consequence, marked improvement in both these regulative process as evidenced from higher accumulation of biomass and further its translocation to the developing yield components (grain) under cultivar Raj 4120 as evident by higher harvest index led significantly increased in grain yield (Table2). Also, grain yield of wheat is further dependent on two most important components, viz., number of grains per unit area and weight of grains (test weight). The higher number of grains per spike or by virtue of increased number of spikes $\mathrm{m}^{-1}$ row length (effective tillers) and higher test weight in cultivar Raj 4120 (Table 1and 2) significantly resulted higher grain yield compared to cultivars Raj 4083, Raj 3765 and Raj 1482. Further, biological yield (total biomass) is a sum of grain and straw yield produced by the crop, thus the increased grain yield and straw yield by Raj 4120 might have resulted higher biological yield. Kumar et al., (2013) reported that the wheat cultivar K- 0307 recorded 2.9 per cent higher spikes $\left(381 / \mathrm{m}^{2}\right) 4.77$ per cent spike length $(9.55 \mathrm{~cm}), 13$ per cent more grain per spike (39) and 10 per cent higher test weight (45.55 g) than that of recorded with wheat cultivars Raj 4229, K- 0906 HD-2733 and DBW-39. This higher yield attributes of K- 0307 can justified owing to favourable temperature requirement as per crop need booting crop growth in the form of higher photosynthetic accumulation and resulting higher yield parameters Patel et al., (1999), Akhtaret et al., (2002) ${ }^{[1]}$ and Kumar et al., (2005) [12].

\section{Bio-regulators}

Foliar spray of bioregulators viz., N- acetyl- L- cysteine (20 ppm) and Salicylic acid (200 ppm) significantly increased yield attributes namely effective tillers per metre row length, spike length, grains per spike and test weight over water spray control (Table 1). Foliar spray of bioregulators enhanced various physiological processes of plant. In cereals, grain yield is the ultimate aim, therefore, the partitioning of dry matter between grain and vegetative parts is of great importance (Donold and Habablin, 1976) ${ }^{[8]}$. While explaining the role of sulphydryl compounds in maize productivity, Sahu and Solanki (1991) ${ }^{[17]}$ opined that higher yield might be resultant of dry matter partitioning. The beneficial role of sulphydryl compounds in improving translocation of photosynthate for yield formation has been proved recently in pot study in Laboratory conditions at BARC, Mumbai and revealed that the efficiency of transportation of labelled sucrose $\left(14^{-\mathrm{C}}\right)$ from leaf, stem and pod of mustard was increased by 88, 44.1 and 35.1 per cent, respectively by foliar spray of SH- compound thiourea (TU) treatments as compared to unsprayed control (Srivastava 2009) ${ }^{[21]}$. It also, enhanced crop growth in terms of plant height and dry matter accumulation per metre row length straw and seed yield. Ali and Mahinoud, (2013) ${ }^{[2]}$ reported that the application of salicylic acid enhanced those traits in comparison with control plants and the superiority in this respect to the high salicylic acid concentration $150 \mathrm{ppm}$ which gave the highest values for these traits as following 24.7, 10.7 and 41.00 percent number of pods per plant, number of seeds per pod and test weight, respectively in the first season and $27.80,11.10$ and 43.90 percent in the second season in the same order. These findings are in a good line which obtained by Singh et al., (1980) ${ }^{[20]}$ and Sujata, (2001) ${ }^{[20]}$.

Table 1: Effect of sowing dates, wheat cultivars and bioregulators spray on yield attributes of wheat

\begin{tabular}{|c|c|c|c|c|c|}
\hline Treatments & $\begin{array}{c}\text { Days to } 50 \% \text { spike } \\
\text { emergence }\end{array}$ & $\begin{array}{c}\text { Effective tiller } \mathrm{m}^{-1} \text { row } \\
\text { length at harvest }\end{array}$ & $\begin{array}{c}\text { Spike length } \\
\text { (cm) }\end{array}$ & \begin{tabular}{|c|}
$\begin{array}{c}\text { Grain per spike } \\
\text { (No.) }\end{array}$ \\
\end{tabular} & Test weight (g) \\
\hline A. Sowing dates & & & & & 40.41 \\
\hline Timely Sowing $\left(20^{\text {th }}\right.$ November $)$ & 82.37 & 86.85 & 10.95 & 40.22 & 37.41 \\
\hline Late Sowing (15 ${ }^{\text {th }}$ December) & 73.63 & 75.37 & 9.94 & 36.55 & 0.32 \\
\hline SEm \pm & 0.80 & 1.27 & 0.08 & 0.38 & 0.94 \\
\hline CD at $5 \%$ & 2.32 & 3.68 & 0.22 & 1.11 & \\
\hline B. Wheat cultivars & & & & & 39.13 \\
\hline Raj 4083 & 80.25 & 82.53 & 10.55 & 39.42 & 37.82 \\
\hline Raj 3765 & 78.63 & 83.30 & 10.37 & 37.14 & 40.74 \\
\hline Raj 4120 & 77.52 & 83.55 & 11.31 & 41.85 & 37.96 \\
\hline Raj 1482 & 75.61 & 75.05 & 9.55 & 35.13 & 0.46 \\
\hline SEm \pm & 1.13 & 1.80 & 0.11 & 0.54 & 1.33 \\
\hline CD at $5 \%$ & 3.28 & 5.20 & 0.31 & 1.57 & \\
\hline C. Bioregulators spray* & & & & & 39.42 \\
\hline Salicylic acid (200 ppm) & 78.01 & 80.83 & 10.68 & 38.82 & 39.95 \\
\hline N- acetyl- L- cysteine (20 ppm) & 80.40 & 84.18 & 11.34 & 40.24 & 37.36 \\
\hline Water spray (Control) & 75.60 & 78.32 & 9.32 & 36.10 & 0.27 \\
\hline $\mathrm{SEm} \pm$ & 0.52 & 0.40 & 0.08 & 0.23 & 0.77 \\
\hline CD at $5 \%$ & 1.48 & 1.13 & 0.21 & 0.65 & 40.41 \\
\hline
\end{tabular}

*Foliar spray at 45 and 75 DAS, NS-Non-significant

Table 2: Effect of sowing dates, cultivars and bioregulators spray on grain, straw, biological yields and harvest index of wheat

\begin{tabular}{|c|c|c|c|c|c|c|c|c|c|c|c|c|}
\hline \multirow{2}{*}{ Treatment } & \multicolumn{3}{|c|}{\begin{tabular}{|l|} 
Grain yield $\left(\mathrm{q} \mathrm{ha}^{-1}\right)$ \\
\end{tabular}} & \multicolumn{3}{|c|}{ Straw yield $\left(\mathrm{q}\right.$ ha $\left.^{-1}\right)$} & \multicolumn{3}{|c|}{ Biological yield $\left(\mathrm{q} \mathrm{ha}^{-1}\right)$} & \multicolumn{3}{|c|}{ Harvest index (\%) } \\
\hline & 2012-13 & 2014-15 & Pooled & 2012-13 & 2014-15 & Pooled & 2012-13 & 2014-15 & Pooled & 2012-13 & 2014-15 & Pooled \\
\hline A. SoWIII & & & & & & & & & & & & \\
\hline $\begin{array}{l}\text { Timely Sowing }\left(20^{\text {th }}\right. \\
\text { November) }\end{array}$ & 29.69 & 26.75 & 28.22 & 37.75 & 35.68 & 36.72 & 67.44 & 62.43 & 64.93 & 43.92 & 42.75 & 43.33 \\
\hline Late Sowing (15 ${ }^{\text {th }}$ December) & 25.93 & 23.36 & 24.64 & 34.59 & 32.91 & 33.75 & 60.51 & 56.27 & 58.39 & 42.40 & 41.50 & 41.95 \\
\hline
\end{tabular}




\begin{tabular}{|c|c|c|c|c|c|c|c|c|c|c|c|c|}
\hline SEm \pm & 0.53 & 0.58 & 0.39 & 0.67 & 0.76 & 0.51 & 1.18 & 1.34 & 0.89 & 0.54 & 0.18 & 0.28 \\
\hline CD at $5 \%$ & 1.60 & 1.77 & 1.14 & 2.02 & 2.30 & 1.46 & 3.58 & 4.07 & 2.59 & NS & NS & 0.82 \\
\hline \multicolumn{13}{|l|}{ B. Wheat cultivars } \\
\hline Raj 4083 & 28.64 & 25.81 & 27.23 & 36.43 & 34.36 & 35.39 & 65.07 & 60.17 & 62.62 & 43.92 & 42.81 & 43.36 \\
\hline Raj 3765 & 26.19 & 23.60 & 24.90 & 35.30 & 33.63 & 34.46 & 61.49 & 57.23 & 59.36 & 42.51 & 41.15 & 41.83 \\
\hline Raj 4120 & 30.93 & 27.87 & 29.40 & 38.97 & 37.04 & 38.01 & 69.90 & 64.91 & 67.40 & 44.19 & 42.85 & 43.52 \\
\hline Raj 1482 & 25.46 & 22.94 & 24.20 & 33.98 & 32.14 & 33.06 & 59.44 & 55.08 & 57.26 & 42.00 & 41.68 & 41.84 \\
\hline SEm \pm & 0.74 & 0.82 & 0.56 & 0.94 & 1.07 & 0.71 & 1.67 & 1.90 & 1.26 & 0.76 & 0.25 & 0.40 \\
\hline CD at $5 \%$ & 2.26 & 2.50 & 1.61 & 2.86 & 3.25 & 2.07 & 5.06 & 5.67 & 3.66 & NS & 0.76 & 1.16 \\
\hline \multicolumn{13}{|l|}{ C. Bioregulators spray* } \\
\hline Salicylic acid (200 ppm) & 28.65 & 25.81 & 27.23 & 36.40 & 34.56 & 35.48 & 65.04 & 60.37 & 62.71 & 43.97 & 42.67 & 43.32 \\
\hline $\begin{array}{c}\text { N- acetyl- L- cysteine (20 } \\
\text { ppm) }\end{array}$ & 29.57 & 26.64 & 28.11 & 37.66 & 35.69 & 36.68 & 67.23 & 63.33 & 64.78 & 43.33 & 42.69 & 43.01 \\
\hline Water spray (Control) & 25.20 & 22.71 & 23.96 & 34.45 & 32.63 & 33.54 & 59.65 & 55.34 & 57.50 & 42.17 & 41.01 & 41.59 \\
\hline SEm \pm & 0.26 & 0.16 & 0.16 & 0.38 & 0.22 & 0.22 & 0.60 & 0.38 & 0.36 & 0.67 & 0.21 & 0.35 \\
\hline CD at $5 \%$ & 0.76 & 0.47 & 0.44 & 1.10 & 0.63 & 0.62 & 1.72 & 1.10 & 1.00 & NS & NS & 1.00 \\
\hline
\end{tabular}

*Foliar spray at 45 and 75 DAS, NS-Non-significant

\section{References}

1. Akhtaret F, Baloch DM, Sadiq SA, Ahmed SS, Hanan A, Taran SA, Ahmed N, Hassan MJ. Plant growth regulators induced drought tolerance in sunflower (Helianthus annus L.). The Journal of Animal and Plant Sciences. 2002; 24(3):886-890.

2. Ali EA, Mahmoud AM. Effect of foliar spray by different salicylic acid and zinc concentrations on seed yield and yield components of mungbean in sandy soil. Asian Journal of Crop Science. 2013; 5(1):33-40.

3. Anonymous. Agronomy results of Co-ordinated experiments. (In) Progress report, (1993-94), AICWIP, Directorate of Wheat Research, Karnal, 1994a, 58-60.

4. Anonymous. Resource management. (In) Progress report (1994-95), AICWIP, Directorate of Wheat Research, Karnal, 1995b, 41-45.

5. Campos AD, Ferreira AG, Hampe MMV, Antunes IF, Branco N, Silveira EP, Silva JB, Osorio VA. Introduction of chalcone synthase and phenyiaianineammonia-lyase by salicylic acid and colletotrichum lindemuthianum in common bean. Brazil Journal of Plant Physiology. 2003; 15:129-134.

6. Chakrabarti N, Mukherjee S. Effect of phytohormones pretreatment on nitrogen metabolism in Vigna radiata under salt stress. Biology Plant. 2003; 36:63-66.

7. Chen W, Chao G, Singh KB. The promoter of a $\mathrm{H}_{2} \mathrm{O}_{2}$ inducible Arabidopsis glutathione-S-transferase gene contains closely linked OBF and OBP 1-binding sites. Journal of Plant Physiology. 1996; 10:955-966.

8. Donnald CM, Hamblin J. The biological yield and harvest index of cereals as agronomic and plant breeding criteria. Advances Agronomy. 1976; 28:361-405.

9. Hayat S, Ali B, Ahmed A. Effect of salicylic acid on growth and enzyme activities of wheat seedling. Brazilian Society of Plant Physiology. 2007; 53:433-437.

10. Khokhar Z, Hussain I, Khokhar B, Sohail M. Effect of planting dates on yield of wheat genotypes in Sindh. Pakistan Journal of Agricultural Research. 2010; 23:4145.

11. Kulhari SC. Studies on the effect of sowing dates and nitrogen levels on productivity of durum wheat (Triticum aestivum Desf) varieties. Ph.D. Thesis, Rajasthan Agricultural University, Bikaner, 2000.

12. Kumar A, Bali Y, Sharma KD, Thakral SK. Evaluation of wheat genotypes for terminal heat tolerance by simple physiological traits. Indian Journal of Plant Physiology. 2005; 13(1):39-43.
13. Kumar P, Yadav RK, Gollen B, Kumar S, Verma RK, Yadav S. Nutritional contents and medicinal properties of wheat. Life Science and Medicine Research. Volume LSMR-22, 2011.

14. Lak M, Farnia A, Shaban M. Effect of different sowing dates on yield components of wheat (Triticum aestivum L.) cultivars in Lorestan Provienes, Iran. Advance in Agriculture and Biology. 2013; 1(4):89-93.

15. Patel NM, Sadaria SG, Kaneria BB, Khanpara VD. Effect of nitrogen, potassium and zinc on growth and yield of wheat (Triticum aestivum L.) Indian Journal of Agronomy. 1995; 40(2):290-292.

16. Sahu MP, Singh D. Role of thiourea in improving productivity of wheat (Triticum aestivum L.). Plant Growth Regulation. 1995; 14:169-173.

17. Sahu MP, Solanki NS. Role of sulphydryl compounds in improving dry matter partitioning and grain production of maize (Zea mays L.). Journal of Crop Science. 1991; 167:356-359.

18. Sandhu IS, Sharma AR, Sur HS. Yield performance and heat unit requirement of wheat varieties as affected by sowing dates under rainfed conditions. Indian Journal of Agricultural Sciences. 1999; 69(3):175-179.

19. Sharma YK, Leon J, Raskin I, Davis KR. Ozone induced response in Arabidopsis thaliana: the role of salicylic acid in the accumulation of defense related transcripts and induced resistance. National Academy of Science. USA. 1996; 93:5099-5104.

20. Singh D, Shamim M, Pandey R, Kumar V. Growth and yield of wheat genotypes in relation to environmental constraints under timely sown irrigated condition. Indian Journal of Plant Physiology. 1980; 17(2):113-120.

21. Srivastava AK, Nathawat NS, Ramaswamy NK, Sahu MP, Singh Nair JS, Paladi RK, D' Souza SF. Evidence for thiol inducel enhanced in site translocation of 14-C sucrose from to sink in Brassica juncea. Environmental and Experimental Botany. 2009; 64:250-255.

22. Sujata A. Performance of wheat (Tritium aestivum L.) varieties in Eucalyptus plantation. Indian Journal of Agronomy. 2001; 50(1):61-63.

23. Suleiman AA, Nganya JF, Ashraf MA. Effect of cultivar and sowing date on growth and yield of wheat (Triticum aestivum L.) in Khartoum, Sudan. Journal of Forest Products and Industries. 2014; 3(4):198-203.

24. Wanger AM. Effect of growth regulators on yield and some physio-chemical parameters in sorghum. Australia Journal of Plant Physiology. 1995; 14(3):360-361. 